matter of pride and to hold to their cherished image of themselves as rugged individualists. The New Deal programmes that have been inherited were attempts to plan the farm economy by doing everything but; it is time to drop the pretence and save a few billion dollars in the process.

Agricultural research, which is a metaphor for the sickness of overall farm policy, has also suffered from short-sightedness. Research programmes arise from the mists to appease some local constituency or deal with some emergency. Painfully absent has been a long-term commitment to solving fundamental problems. A genuine investment in basic research in plant molecular biology - which means considerably more than the still-token effort to establish a peer-reviewed grant mechanism for agricultural research - could pay off in lower input costs to farmers by cutting their dependence on energy-linked tillage, fertilization, irrigation and pest-control costs. That in turn could do much to reduce the expansionary pressures on farmers that are now answered by taking out more and more loans and overproducing.

\section{Imbalanced budgets}

\section{Next week's British budget could be decisive for the future of British industry and innovation.}

CAN governments do anything at all to revitalize an economy fallen on bad times? In a blend of disappointment and despair, this is likely to be the Britsh government's unspoken question about its revenue budget for the year beginning 1 April, due next week. For outwardly the government should now be basking in the rewards of six years of virtue. Learning from the mistakes of its predecessors since 1964, but also for doctrinal reasons, the present government has avoided, almost, direct intervention in the pattern of industry. Consistently it has been saying that governments can hope only to create the climate in which economic growth and thus prosperity will emerge. But eschewing direct intervention, governments must fall back largely on fiscal measures, whence the importance of next week's budget. The worry for the British and their government is that six years of almost consistent budget-management have so far produced only one tangible success - the inflation rate is a modest five per cent a year. Otherwise, unemployment continues to grow while the slow growth of the Gross National Product in the past few years consists largely of the expansion of service industries. Manufacturing industry (apart from oil) is still producing less than in 1979. And now interest rates are higher, and sterling lower, than ever before.

What has gone wrong? Why has so much effort been so poorly rewarded? From the outset, one of the government's key objectives has been to reduce the proportion of the national income spent by local and central governments, in the twin belief that the proportion has become too high and that, if the level of taxation were reduced, people would have more to spend in ways that would stimulate the economy. More recently, the same British government has been saying that direct taxation (on income) should be replaced by indirect taxation (on spending) because people could then choose investment rather than consumption.

Three things have caught the British government napping. First, public spending has remained high as a proportion of the total because of the growing social costs of unemployment and longevity, but also because spending on essential services such as education is so meagre that it cannot easily be cut. Second, when people have extra money because they pay less tax, they (or the financial institutions that hold their savings) are as likely to invest in industry elsewhere as in Britain. That is why there is something in the view of those economists who argue that restrains on capital outflows would bring immediate prosperity. (The snag is that the short-term would be very short.) Third, the government's actions have not been nearly as consistent as its rhetoric. Last month's sterling crisis seems to have been partly triggered by a belief that the government was allowing the money supply to grow in a way contrived not to show up in the accepted monetary statistic-but can it make sense to spend at least $£ 10,000$ million to replace Polaris nuclear submarines by Tridents at a time like this? (An Anglo-French accommodation on nuclear weapons would be cheaper and militarily prudent.)

Signs that the British government is beginning to lose its composure are, in the circumstances, inevitable but significant. With the sterling crisis, last month was replete with signs of fraying nerves. Even more remarkable was an attack delivered last Friday by Mr Nicholas Edwards, Secretary of State for Wales, on the financial institutions of the City of London. Mr Edwards accused them of "prejudice, ignorance and a striking lack of awareness" of what is happening in modern industry. He singled out an electrical and defence contractor, the General Electric Co. PLC, for having accumulated large amounts of cash (in excess of $\mathfrak{1} 1,500$ million) and for turning itself "into an investment bank" rather than investing in innovation. But what else can $\mathrm{Mr}$ Edwards expect, when his own government is prepared to offer people a rate of interest as much as ten per cent above the inflation rate, and when the rewards of innovation are unlikely to be as great?

That is the clue to the fiscal part of the solution to the problem of encouraging reinvestment in British enterprise. British interest rates are at present high not merely because they are tied to interest rates in the United States but because of the money mismanagement rumbled a month ago. The way to bring them down, and to cut the inflation rate, is further to reduce public spending. Tax cuts would work in the same direction but less quickly. The government's difficulty is that it has cut most things to the bone already, so that there is little scope for further manouevre. Sooner or later it will have to bite the defence bullet, and the sooner the better. Certainly there is little hope that productive investment can be stimulated by devices such as the ill-starred Business Expansion Scheme, which offers exemption from income tax for five-year investments in new business, and which seems chiefly to have stimulated property development. The moral, for those who like their fiscal policies to be clean and tidy (like the present government) are that a belief that the market knows best is incompatible with attempts to rig it. The moral for those who say that Britain is good at invention but poor at exploitation is that the explanation may lie in fiscal mismanagement.

\section{Polish normalcy?}

\section{Is the Polish government serious in saying it wants normal relations with the outside world?}

THE account of Polish science by Vera Rich on page 123 says nothing of the circumstances in which the information was gathered. Ms Rich left London for Warsaw three weeks ago, on a visa provided by the Polish Embassy in London. The visa was due to expire at midnight on Tuesday, 26 February. Protesting in London that she planned to return on a charter flight only on the following day, 27 February, Ms Rich was told that there would be no difficulty if she left on the first flight that day.

On the morning of 27 February at Warsaw airport, the first flight was delayed for several hours, until 11 a.m. On exit, Ms Rich was told that her visa was not in order, she was stripped and searched, a number of documents and audio-tapes were confiscated and Ms Rich was bundled into the waiting aircraft. She returned to London in great distress, humiliated and shocked.

The Polish government is understandably ambivalent towards journalists, especially those from abroad. It rightly regards a reasonable trickle of such people as a proof that normalcy has returned, but it cannot apparently stomach, or even understand, journalists' inevitable curiosity about the events of the past four years. Not that Ms Rich's too-brief visit to Warsaw last month was in any way subversive - most of her meetings with of ficials were arranged under government auspices anyway. The Polish Embassy in London has not yet replied to a request for an explanation of why Ms Rich was bundled out of Warsaw in such an outrageous fashion. This note is meant to jog the embassy's memory. The explanation, if forthcoming, will of course be published. 